\title{
咀嚼器官および消化器官の生後発達 とその制御要因について
}

\author{
前田憲 彦久米川正好 \\ 城西歯科大学・ 口腔解剖学第一講座 (主任 : 久米川正好教授)
}

[受付 : 昭和59年 8 月 28 日]

\section{Review \\ Postnatal development of masticatory and digestive organs and their regulation factors

\author{
Norihiko Maeda and Masayoshi Kumegawa \\ First Department of Oral Anatomy, Josai Dental University, Sakado, Saitama 350-02
}

(Chief: Prof. Masayoshi Kumegawa)

[Accepted for publication: August 28, 1984]

Key words : postnatal development/masticatory organs/digestive organs/regulation factors

\begin{abstract}
Postnatal development of masticatory and digestive organs and their regulation factors were reviewed.

In the morphogenesis of the skull, the differentiation of the chondrocranium is almost exclusively governed by intrinsic genetic factors, but the desmocranial growth, particularly in the upper and lower jaws, is influenced by many epigenetic factors originating from adjacent head structures and by local environmental factors occurring in form of pressure and tension forces from the masticatory muscles and other soft tissues. Each of the soft tissues associated with various functions in the skull was termed the "functional matrix" by Moss (1968). Growth and maintenance of the skull unit may depend exclusively upon its related functional matrix.

Moreover, in a series of experiments using rats and mice, it was shown that hormones and diets affected the postnatal development of the skull. Also, in the masticatory muscle and parotid gland, these factors influenced their development, and the same controlled the postnatal development of other digestive organs like the stomach and pancreas. Thus, in the masticatory and digestive organs, many factors are involved in their development, and some of these organs are controlled by the same factors. Moreover, recently, many regulatory factors for bone formation have been found in vivo and in vitro. Therefore, further studies are needed for analysis of the control factors involved in the postnatal developmnt of masticatory and digestive organs, their regulation systems and interelationships between them.
\end{abstract}

\section{1.はじめに}

咀嚼器官とは，歯，それを支持する上下の顎

埼玉県坂戸市けやき台 1 の（预350-02）
骨，顎関節，咀嚼笳群，舌，口唇，および広くは これらを支配する神経系等を含めての総称であ る。離乳現象を持つ哺乳類では, 咀嚼器官の質 的, 量的転換には, 母乳から個々の動物本来の食 
性である食慨への転換というエネルギー摂取様式 の変化, すなわち, 消化器官系の質的転換をとも なわなければならない。

さらに，地球上には現在多くの種が歴史的な適 応放散の結果存在しているが，種の進化過程にお ける, 咀嚼器官系の位置は重要であり, その適応 形態は実に様々である。例えば，爬虫類より下の 脊推動物の歯や顎の構造は, 彼らの食性の性格 上, 咀嚼作用を必要とせず，主として捕食，闘争 などに使われる単純な形態を持っているが，哺乳 類にいたっては個々の種の食性の拡大にともな い, 歯の形態が複雑化し，顎構造および顎運動が 多様化している。とくに, 咀嚼器官が, 自然界に おける, 種内, 種間闘争のための武器, および捕 食のための手段としての役割から解放された人類 の場合，およそ，ありとあらゆる食物を食べるこ とが可能なように咀嚼器官系が分化, 発達してい る。それだけに発達様式も複雑である。

これらのことを考慮すると, 咀嚼器官および消 化器官の生後発達について一元的にまとめること は不可能に近い。とはいえ，高齢化現象などによ り，歯科医療の対応の多様化と統合性が必要とさ れる現代社会の状況下で，最も基礎的問題である これらの器官の成長，発育および維持に関する総 合的研究の需要性は, 今後, ますます増大寸ると 思われる。そこで, 本総説では, 咀嚼器官および 消化器官の発達に関する先人の研究, ならびに, われわれの研究のなかから，生物界に共通する現 象が抽出できるかどうかを試みるとともに，今後 の研究の展望について述べる。

\section{2. 上・下顎骨を含む顎顔面の発 達とその制御要因について}

咀嚼器官の最も基本的要素である上顎および下 顎骨の原型は胎生期にすでにすべてできあがって いるが, 生後, 咀嚼器官として作用するために は，離乳期に向けて大きく改造される必要があ る。

骨は軟骨性と結合組織性の両者によって形成さ れることが知られているが，頭蓋骨においては， 軟骨結合のうち蝶形後頭軟骨結合部が 17歳前後ま で存在するのみで， あとは $2 \sim 4$ 歳で閉じられて
しまうと言われている ${ }^{1)}$ 。そうだとすれば，頭蓋， 顔面の発達はその大部分が，生後初期を除けば結 合組織性の骨形成によっておこっていることにな る。しかしながら，頭蓋と顔面のような，しかも 複数の要素によって形成されている複合体では， それが本来の姿に成長, 発育するためには，個 々の要素がいかにバランスをくずすことなく成 長, 発育していくのかが重要な問題となる。そし て，それを制御する要因は何か。ここでは，こう いった問題について述べる。

頭蓋骨の成長を考えるにあたって，これまで， いろいろな制御要因が考えられている。内在的遺 伝要因, 局所的個体新生要因, 一般的個体新生要 因, 局所的環境要因，および一般的環境要因等で ある。これらのうち, どれを主要因とみなすかは 研究者によって異なっている。そこで, これまで 研究者によって提唱されている仮説の主なものを 紹介する。Weinmann と Sicher ${ }^{2)}$ は内在的遺伝 要因が頭蓋骨組織自体の成長, 発育を制御する主 要因であるとしているが，彼らの説は，例えば， 関連する（あるいは隣接する）組織間で, 劣成長 や過成長が生じた場合，その成長異状が隣接する 頭蓋骨要素に影響するという実験結果等によって 疑問視されている3!。

これに対して $\operatorname{Scott}^{4)}$ は内在的遺伝要因を考虑 しながら, 局所的個体新生要因と局所的環境要因 によって頭蓋の成長は支配されているとしてい る。そして, 内在的遺伝要因が軟骨成長および骨 膜性成長を支配し ${ }^{5-9)}$, それによって一次的におこ る軟骨性の成長が，二次的に縫合性成長を特に刺 激する。さらに，それは局所的環境要因および局 所的個体新生要因によっても刺激されるというの である。このような理論は，例えば，軟骨性成長 は，圧力や張力などによって直接的な影響を受け ないが，結合組織性の骨の成長は影響を受けると いう Hinrichsen と Storey ${ }^{10)}$ の実験結果などに よって支持される。もっと具体的な例としては, 鼻中隔の一次的な成長は上顎骨の二次的成長を促 進すると主張した $\mathrm{Scott}^{4}$ ) の研究や, 鼻中隔の重 要性を強調したその後の多くの研究が上げられ る $^{11-15)}$ 。さらに, 鼻中隔は, 隣接部分の骨の上下 方向への成長よりも，前後的な成長にとってより 
重要であることまでわかってきた ${ }^{16,17) 。 ~}$

このような Scott の説に対して, Moss は骨膜 性成長も縫合性の成長と同様に二次的におこるも のであるとした ${ }^{18-20)}$ 。そして，軟骨性頭蓋の成長 と結合組織性の頭蓋の成長を同格にあつかい，成 長途上にある頭蓋骨そのものに内在する制御機構 は存在しないと主張している。彼の説で特筆すべ きは functional matrix (機能的成長発育の場)の理 論である 21-24)。では functional matrix とは一体 何か。これを理解することは Hunter や Enlow ${ }^{25)}$ によって示された成長にともなう上顎骨や下顥骨 の複雑な成長様式の解釈および 説明するうえに不 可欠である。すなわち，頭部を多機能性をそな えた複合体とみなした場合，ある一つの機能に関 連した骨格と軟組織を合せて functional cranial component と定義した。そして，その軟組織の部 分を functional matrix と呼んで，成長時において 骨性組織の形態形成を運命づけると考えてい $3^{21-24)}$ 。Moss ${ }^{26)}$ は, 頭蓋骨の形態形成の多くがこ れによって支配されると考えていたようである。 functional matrix が顔面の成長の支配要因である ことを示す具体例としては，咀嚼器官に属する咀 嚼筋と頭骨との関係についての研究がある ${ }^{27-34)}$ 。 そういった仕事の多くは，咀嚼筋の切断が䪽骨人 どう影響するかを調べている。筋肉切除実験は少 なからず顎骨の 形態変化を引きおこすが，Schumacher $^{32)}$ が示したように，イヌとヤギのような， 元来肉食性の動物と草食性の動物では全く異なっ た現象のおこることがある。例えば，ヤギでは， 上䅡骨は咀嚼筋が切除された側に曲がるが，イヌ では切除された側の反対側に曲がる。これは，上 顎骨の形態形成に functinal matrix である笳肉 に他の要素, すなわち，両者の動物の䪽関節の構 造の違い，および，それによる顎運動様式の差と いう，局所的環境要因が関与している良い例であ る。直接, 筋を切除する実験に対して, 咀嚼筋を 支配する神経を切断することによる影響を調べ た実験でも，顎骨に対して筋切除時と同じような 結果が得られている35-37)。これも Moss の主張す る functional matrix による支配と言えなくもな いが， 神経切断が直接的に効くのか，あるいは， 咀嚼筋の tension を低下させるという functional matrix である咀嚼筋の環境要因としての状態が変 化した結果，二次的におこるものなのかは悠密に は決定できない。さらに，functional matrix を支 持する一連の研究が Koski と Rönning によっ ておこなわれた ${ }^{38-42)}$ 。その内容の要点は，長骨の 骨端軟骨を脳内に移植した場合は軟骨性骨端は元 来の長骨としての発育像を示すが, 同じく移植さ れた咀嚼器官の下顎頭軟骨は成長しないだけでな

く，本来の構造を失なったというのである。

このように functional matrix を成長の制御要 因と規定すると，頭蓋骨の成長を説明するのに合 理的であるが, 成長期における頭蓋骨の連続的変 化を説明するには，もちろんこれだけでは十分で はない。とくに，哺乳類全般に共通する現象であ る離乳期については, あとで述べる理由によって， その説明が困難である。すなわち，離乳期には歯 の萌出という， 新たな要素が加わると同時に，栄 養摂取様式が母乳の吸啜から固型物の咀嚼人と転 換するために顎運動様式が変わる。連続的に成長 する頭蓋骨の個々の構成要素の間には，成長速度 の差および成長方向の差が存在する。

すでに，Scammon ら ${ }^{43)}$ は身体各部の成長様式 が，組織の種類によって異なることを示し， そ のタイプを, 全身型, リンパ型, 神経型, 生殖 器型に分類した。そして，脳頭蓋の成長は神経 型の 成長様式に 類似し，とくに幼年期には 全身 型成長様式をとる顔面頭蓋の成長に先行すると主 張している。しかし，20歳までには両者の成長の 割合が一致することを示した。最近 Maeda ら ${ }^{44)}$ は，離乳期をはさんだ脳頭蓋部と顔面頭蓋部の生 後発達についてラットを用いて調べている。その 報告で Maeda らは，離乳以前は脳頭蓋部の成長 が顔面頭蓋部の発達に先行し，ヒトの思春期に相 当する40日㱓に到ると，やはり，両者の成長が一 致することを示した（Fig. 1)。しかも，離乳期 の前後で，顔面頭蓋部の成長を制御する因子が異 なることを明らかにした（Fig. 2)。すなわち，離 乳前の生後初期において, 甲状腺ホルモンと副腎 皮質ホルモンの投与が頭蓋骨の 顔面頭蓋部の成長 を促進するが，離乳期が近つくにつれてホルモン の影響は徐々に減少した。では，離乳期以後の顔 面部と頭蓋部の成長比に関与しているのは何か。 


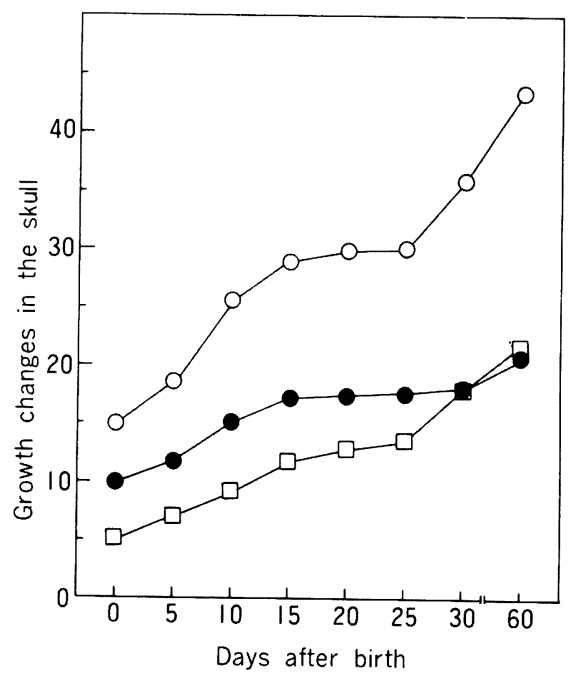

Fig. 1 Postnatal development of each part of the rat skull. $\bigcirc$, total length; head length; $\square$, facial length. In developing rats, rapid increases in the total length of the skull occurred from day 5 to 10 and from day 25 to 30 after birth. The first rapid increase in the total length of the skull on days 5-10 was due to the parallel growth of the head and facial parts of the skull, and the second rapid increase was due to the larger rate of increase in the facial part of the skull over that in the head part (Maeda et al. $)^{44)}$.

そこで，咀嚼作用を抑制したラットについて，こ の比率をコントロール群と比べた結果, 顔面部の 頭蓋部に対する比率が減少していることがわかっ た。このように，ヒトとラットという全く異なる 種間で，脳頭蓋部と顔面頭蓋部の成長パターンに 共通する部分があるのは興味深いことであり，実 験系としてのラットの利用価値を示している。 $\mathrm{Moss}^{45}$ が口腔顔面部の成長と咀嚼筋の使用類度と の相関関係について調べた研究からも functional matrix としての咀嚼筋の活動が，まぎれもなく上 顎を含む口腔顔面部の 成長制御要因であると考え られる。

さらに,このような実験結果は Scott や Moss の下頢骨の成長についての仮説を裏づけるもので ある。二人の説には多少の違いがあるが，いずれ も, 下頡骨の形態形成が，付着する咀嚼筋と萌出し てくる歯の影響下にあるとい5ものである ${ }^{12,46)}$ 。

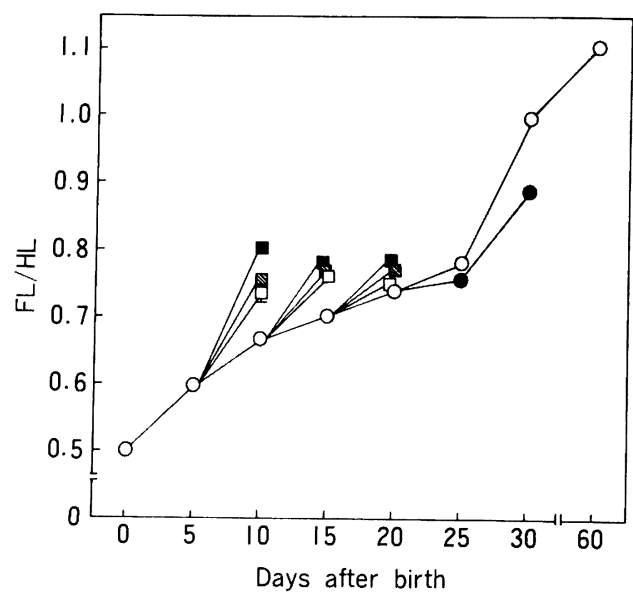

Fig. 2 Changes in the ratio of facial length to head length in developing rats and effects of hormones and mastication on postnatal development of the facial

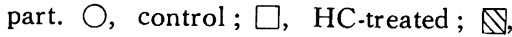
$\mathrm{T}_{4}$-treated; $\mathbf{\square}, \mathrm{T}_{4}$ plus HC-treated; $\mathbf{O}$, prolonged suckling group. Hormones were given for 5 consecutive days, beginning on day $5,10,15$, or 20 after birth (Maeda et al.) ${ }^{44)}$.

筋の付着部（下顎角や筋突起等）には，咬筋，内 側翼突筋，側頭筋等がまず functional matrix と して成長に影響し，これらの筋の機能が局所的な 環境要因として最終的に下顎骨の 形態を 決定す る。さらに，萌出する歯は歯槽骨の成長と保持に 役立っている。したがって，筋機能の低下や歯の 脱落は，それらの部分の形態をそこなうことにな る。

一方，ラットの実験でも示されたように，成長 制御因子の究明には，内因性要因として，内分泌 現象に目を向ける必要がある。

$\mathrm{Krogman}^{47)}$ は出生から成人にいたるまでの肉体 的特徵を調べたが，そのなかで，頭蓋，顔面部の 成長と歯の萌出の関係を調べるとともに性ホルモ ンの血中レベルを測定している。Spiegel ら ${ }^{48)}$ は 幼児期からの甲状腺機能減退症の患者に, 歯の萌 出の遅延と位置異常や乳歯の晚期残存および，異 常な歯根の吸収等が正常人よりも多いことを認め ている。これとは逆に，甲状腺ホルモンおよび副 腎皮質ホルモンの投与が歯の萌出を早め, 離乳を 促進することを前田ら ${ }^{49)}$ は確認している。 


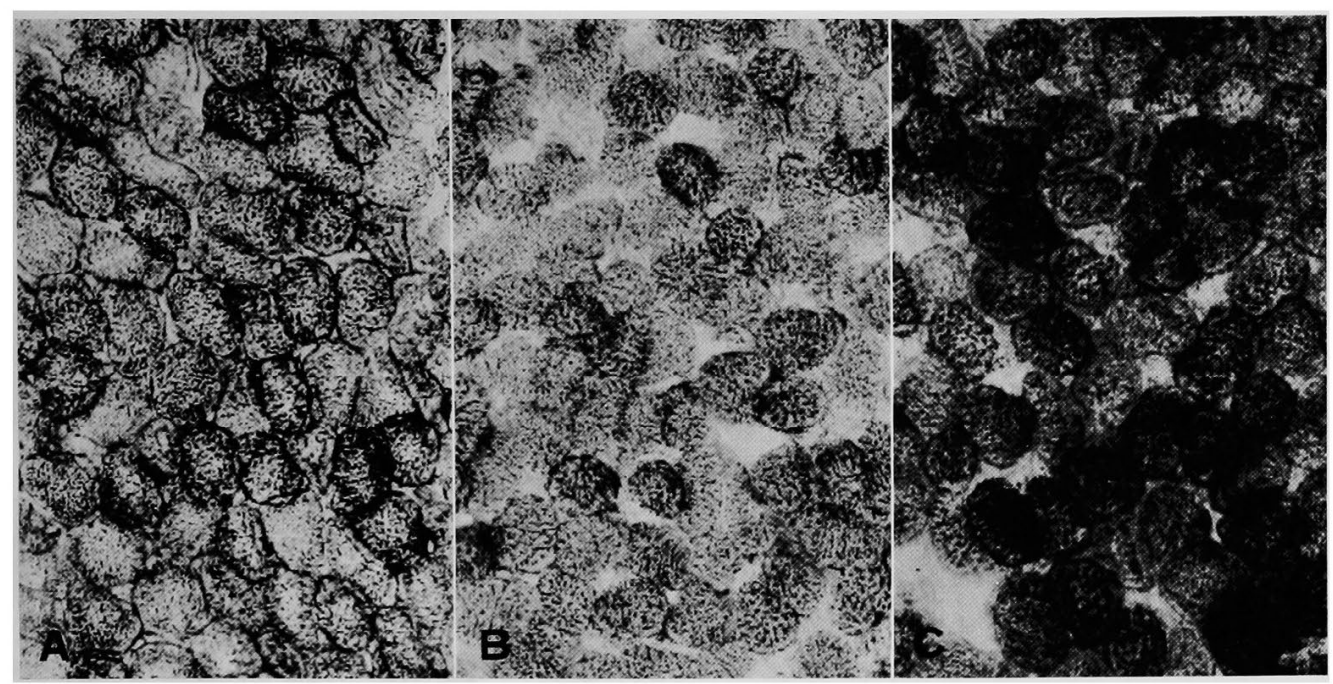

Fig. 3 Effect of mastication on $\mathrm{SDH}$ activity in the $M$. masseter superficialis of rats on day 25. A. control rats; B, rat after suckling till day 25, C, rat after forced weaning on day 17. $\times 195$. The SDH activity in the muscle fibers was low, especially in the peripheral parts in rats which continued suckling until day 25 after birth, but it was increased in rats forced-weaned on day 17 (Maeda et al.) ${ }^{102)}$.

Scott や Moss の言うように，歯が䪽骨の制御 要因として関与しているならば，この分野の複合 的な研究が，今後クローズアップされることにな るだろう。

さらに，体内で作られたり，外から経口的に取 り入れられたりする微量な物質（例えばプロスタ グランディン，トランスフェリン，活性型ビタミ ン $\mathrm{D}$ 等）が歯の萌出や骨形成に関与しているとい う研究成果 ${ }^{50-55)}$ が昨今急速に増えていることも合 せて考えると，全身的内因性の問題と顎顔面の発 達に関する研究，とくに離乳期前後を対象にした 課題が設定されなければならない。

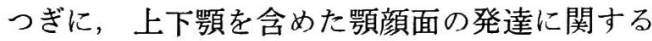
要因のなかでもとくに重要で, functional matrix あるいは局所的環境要因として位置ゔけされる咀 嚼筋について話を進める。

\section{2. 咀嚼筋の生後発達とその制御因子}

咀嚼筋が顎顔面の発達に 関与していることにつ いては少し説明したが，もっとわかりやすく説明 するためには，笳肉に関するより深い理解と，咀 嚼筋の系統発生的問題, さらに，骨格笳の成長制 御因子等についての深い理解が必要である。
近年，骨格筋は，電子顕微鏡の発達にともな い, ミトコンドリアや筋小胞体の量および分布状 態等によって，赤筋線維 (red fiber) と白筋線維 (white fiber) に分類されている ${ }^{56)}$ 。Edgerton と Simpson ${ }^{57)}$ は骨格筋を構成する筋線維をさらに分 類して, red fiber と white fiber, その中間タイプ のintermediate fiberに分類した。これらの三つの タイプ骨格筋について Barnard ら ${ }^{58)}$ や Burke ら ${ }^{59)}$ がさらに詳しく調べて, 構造, 機能, 組織化学的 性質等が異なっていることを確かめた。さらに， 多くの研究者が様々な動物の咀嚼筋について調べ た結果, 咀嚼筋を構成する筋線維の種類は種によ って異なることがわかっている。これは, 筋肉の 持つ機能と深いかかわりを持っている ${ }^{60-71)}$ 。一方, Suzuki ${ }^{68)}$ は顎運動様式の異なる数種の動物の咬筋 を組織化学的に調べて，筋肉の組織化学的性質 は機能と関係があることを示唆している。例え ば，牛や羊のような反留動物では，1日のうちの 4〜9 時間が反忽のために費やされており, chewing の回数が 24000-39000にも及ぶことを観察 している。それに関連して，咀嚼筋における $\beta$ hydroxybutylate や脂肪の酸化能力が増大するよ う適応しており, 組織中の NADHOX, HBOX 


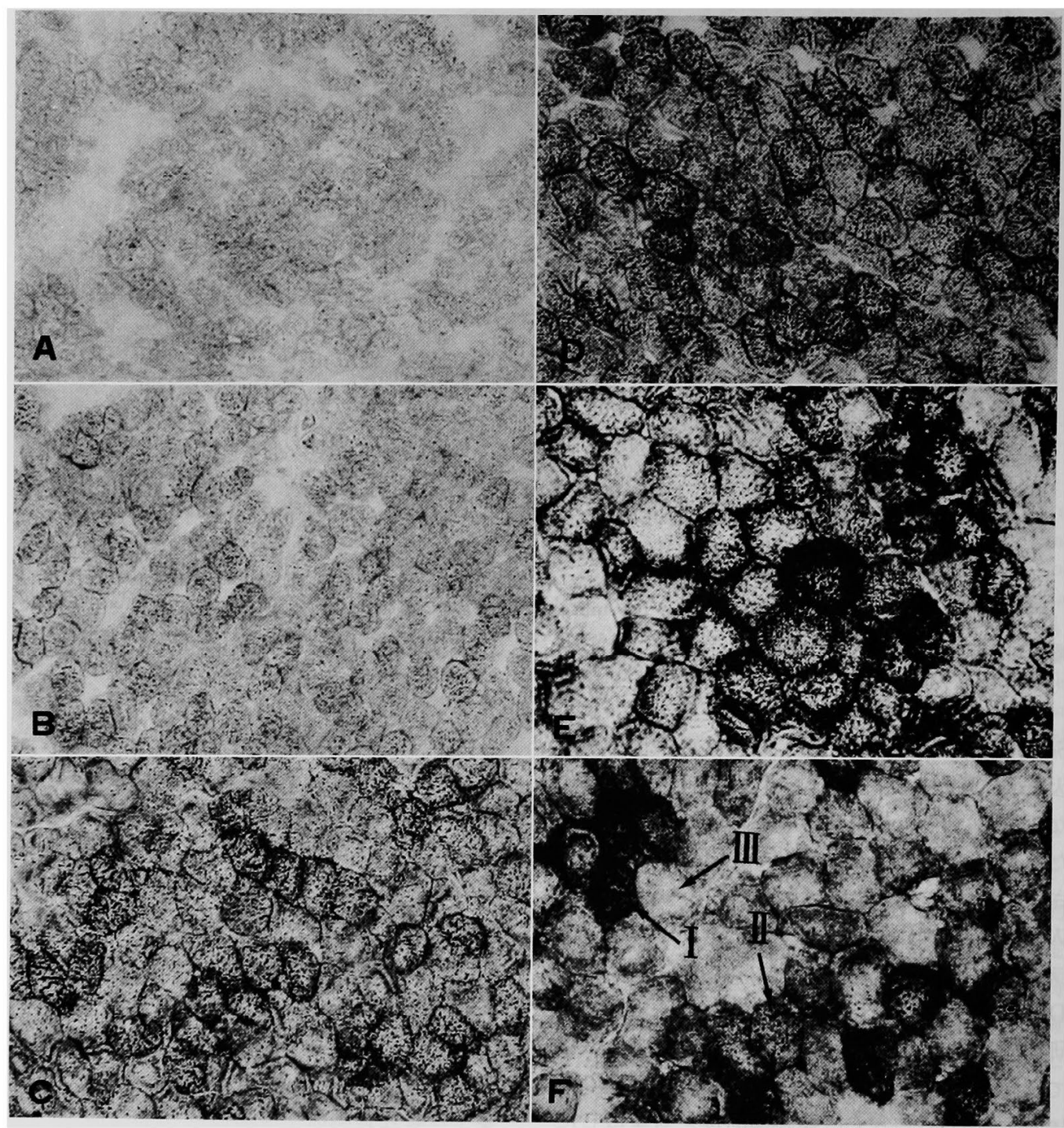

Fig. 4 Histochemical appearance of SDH in the M. masseter superficialis in developing rats. A, 10-day-old ; B, 15-day-old ; C, 20-day-old; D, 25-day-old; E, 30-day-old ; F, 35-day -old. $\times 195$. After the 20th postnatal day, 2 types of fibers were detectable, and from 30 to 35 days after birth, 3 types of fibers appeared in the M. masseter superficialis (Maeda et $a l.)^{71}$.

やSDH の活性が高いと言われている。

このような, 食性, および, それにともなう顎 運動様式, 使用頻度の差に応じて適応している筋 肉の成長を制御している要因に関寸る研究につい て紹介する。Takasu と Hughes ${ }^{\text {(2) }}$ はヒトの骨格 筋では胎生の 20 週までは LDH の isozyme のパ ターンが筋の種類によって異なってくることを示 した。このような, 成長期における筋の生化学的
性質の転換に 関与しているものは何か。これに は，いろいろな要因が可能性として考えられる。 例えば, 様々な種の色々な筋肉の 筋線維構成が異 なっていることを考え合せれば60-71,73-77)，遺伝的 な要因による発達の制御機構についても考虑され るべきだが，直接この要因について調べた研究は 見当らない。今後, 積極的に研究が進められるべ きである。 


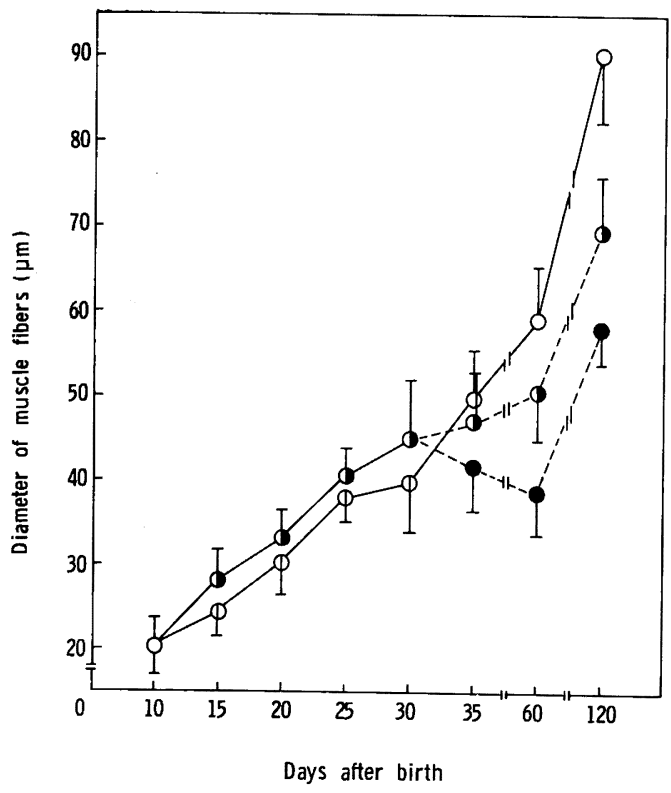

Fig. 5 Relationship between change in diameter of fibers and their SDH activity. Values are means for 25 fibers from 5 animals. fibers with high SDH activity; 1 , fiber with intermediate activity; $\mathbb{D}$, fibers with transitional activity; $\bigcirc$, fibers with low activity (Maeda et al.) ${ }^{71)}$.

これに対して，筋肉の分化を促進する要因とし て，具体的結果が得られている例は多い。まず, 神経支配による筋の分化の 制御に関する実験が, Buller ら ${ }^{78}$ によって行なわれた。それによると， ネコの Soleus（赤筋タイプ）を支配する神経と Flexor hallucis longus（白筋タイプ）を支配 する神経を一度切断して，再び交叉接合する “cross innervation”実験を行なうと，筋肉の生 化学的性格が入れかわることが明らかにされてい る。その後も，筋線維の性質決定における神経支 配の重要性についての論文は多く出されてい $ろ^{79-85)}$ 。

さらに, 神経と筋肉の分化との関連性について 興味深いことがわかっている。主に屈筋群，つま り咀嚼筋では䫟挙上筋に分布している 筋紡錘内の 錘内筋線維の分化が Ia と呼ばれる求心性神経の 接触によって引き起されるという報告 ${ }^{86-88)}$ は，錘 外筋線維（一般的な骨格筋線維） が運動性神経の innervation によって運命づけられていることと

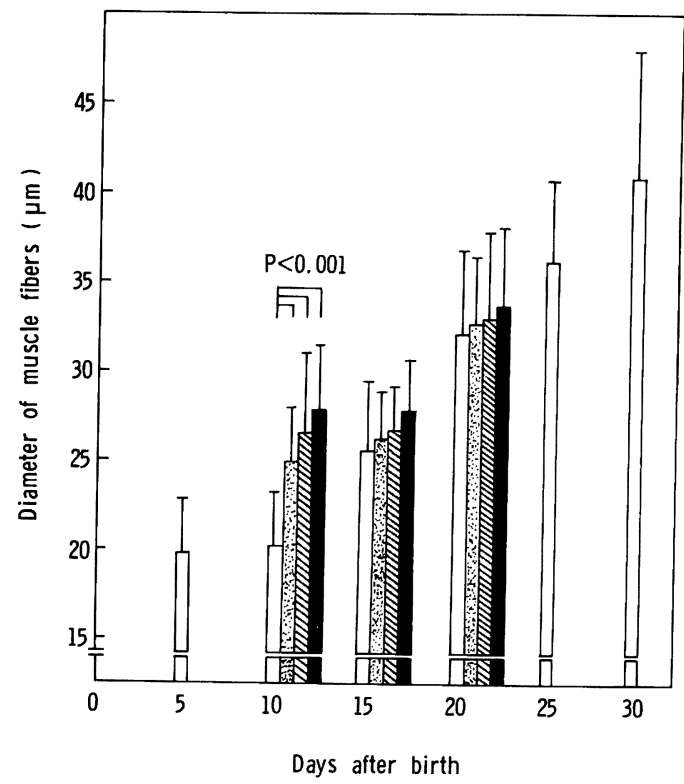

Fig. 6 Effects of thyroxine (T4) and i or hydrocortisone (HC) on diameter of muscle fibers in intact rats. $\square$, control; $\square$, HC-treated; $\mathrm{T}_{4}$-treated;, $\mathrm{T}_{4}$ plus HC-treated. Hormones were given for 5 consecutive days, begining on day $5,10,15$, or 20 after birth (Maeda et al. ${ }^{106)}$.

比べて対照的である。

なお，咀嚼筋の筋紡鍾は，咀嚼筋群でも，筋肉 によって，また動物によって（これは，言い換え れば食性の変化による顎運動の 違いによって),

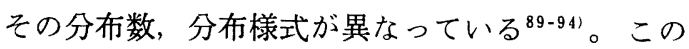
ことは，筋紡鍾が顎運動機構の主役である咀嚼筋 の運動制御に大きく関与していることを示㖫して いる。

また, 咬笳に分布する笳紡錘が，一見何の関係も ない眼窩下神経の切断によって，電顕レベルでの 変性をおこすという最新の発見 ${ }^{95)}$ は，頡運動に関 与寸る高次中枢の複雑性を物語っているだけでな く, 顎骨の発達に対して咀嚼笳が functional matrix あるいは局所的環境要因として働くことを前 提として考えれば, 咀徱筋の発育, 成長に関する 神経学的側面からの研究が, 多様化と統合化とい う，一見相反する次元で同時に進められなければ ならないことを示すよい例である。

神経支配による筋の発育, 成長に関連して, 長 


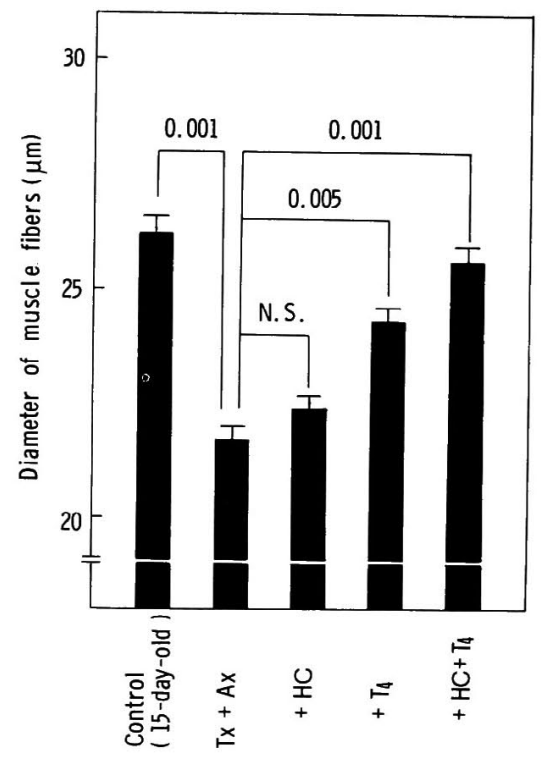

Fih. 7 Effects of $\mathrm{T}_{4}$ and/or $\mathrm{HC}$ on diameter of muscle fibers in thyroidectomized-adrenalectomized rats. Both operations were done on day 8 after birth; $\mathrm{T}_{4}$ and/ or HC were given on days 10-14 after birth, and animals were killed on day 15 . The values 0.001 and 0.005 indicate significances of differences by the t-test. N. S., not significant; Tx, thyroidectomized; Ax, adrenalectomized (Maeda et al.) ${ }^{106)}$.

時間におよぶ笳肉の training や overload の問題 が上げられるが，これらもまた筋肉を構成する筋 線維の性質に影響を与えることが知られている ${ }^{96-}$ 101)。離乳の進行にともなう咀嚼頻度の増大は, 咀 礵筋の広義の意味での training とも考えられ, 咀 嚼筋そのものの発達に重要な 役割を果していると 思われる。これについて, Maeda ら ${ }^{1021}$ が咀嚼活 動を抑制, あるいは促進させた離乳期前後のラッ トの咬筋について調べたところ，咀嚼作用が咬筋 を構成する筋線維の組織化学的性質等の発達に関 与するという結果を得ている (Fig. 3)。また，歯 の脱落によって正常な咀嚼ができないようになる と筋肉の組織化学的性質に変化がおこることもし られている103)。

つぎに，咀嚼筋についても，頭蓋骨の成長，発 育の場合と同様, 成長, 発育に関与する内分泌的 要因について触れておく必要がある。

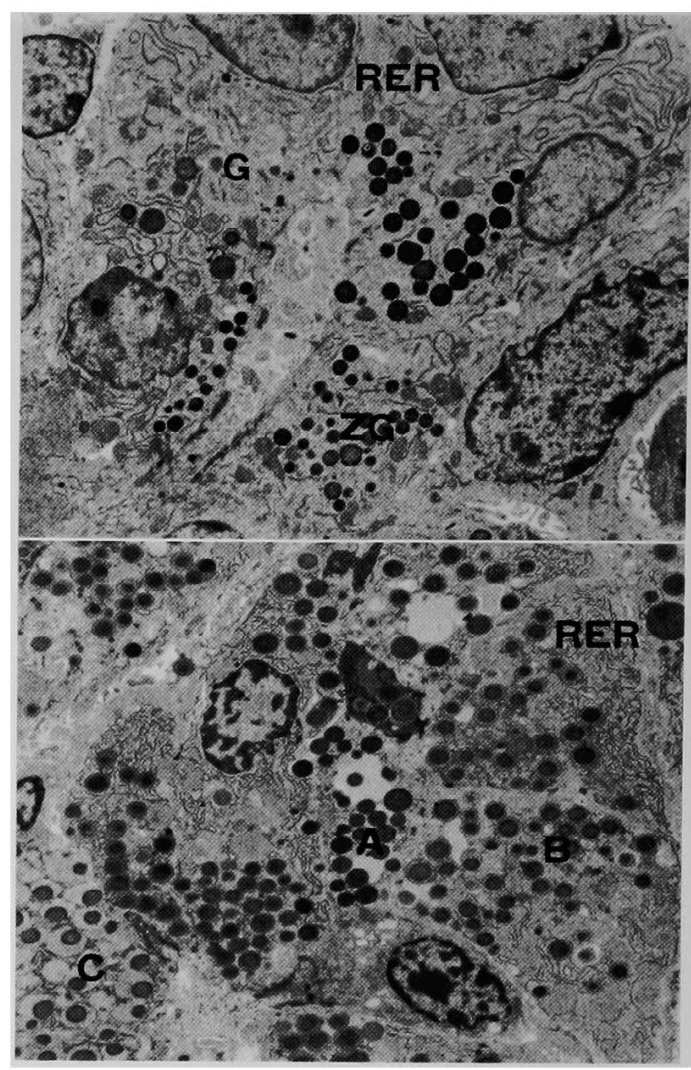

Fig. 8 Electron micrograph of the parotid gland of an untreated mouse on day 11 after birth (Top). Little rough surface endoplasmic reticulum (RER) or Golgi complex (G) is seen. The zymogen granules $(\mathrm{ZG})$ are electron-dense. $\times 2,100$. Electron micrograph of the parotid gland from a mouse after daily subcutaneous injections of hydrocortisone from day 6 after birth (Bottom). Much rough surface endoplasmic reticulum (RER) and many granules are seen. The granules are polymorphic; some are homogeneous and electron-dense (A), having a large (B) or a small (C) central core. $\times 2,100$. (Takuma et al.) ${ }^{121)}$.

Kubistaら ${ }^{104)}$ は甲状腺ホルモンが slow (red) お よび fast (white) と分類される筋肉の Soleus と Rectus femolis の解糖系の 酵素の 活性パター ンに影響を与えるといらデータを出している。ま た, Gutmann ${ }^{105)}$ は Levator ani muscle が Androgen-dependent な筋であると報告している。 一方, Maeda $5^{106)}$ は, 頭蓋骨の場合と同じ離 


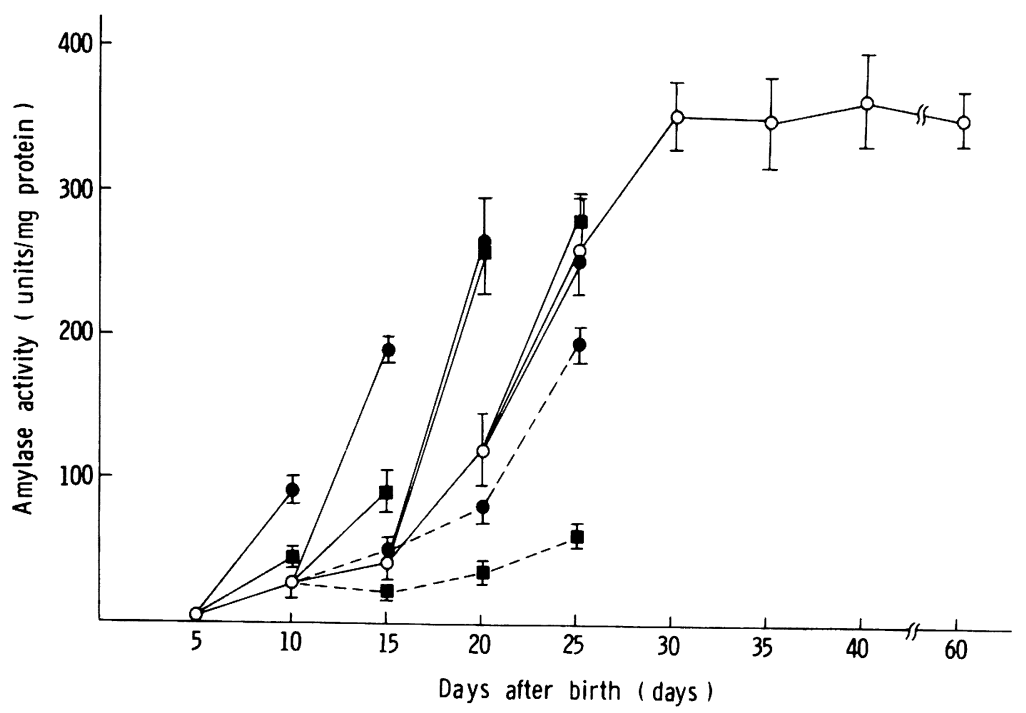

Fig. 9 Effects of hormones and adrenalectomy or thyroidectomy on rat parotid gland amylase activity. Values are means $\pm \mathrm{SD}$ for six animals. $\mathrm{O}-\mathrm{O}$, control ; $-\bullet$, thyroxine $(0.2 \mu \mathrm{g} / \mathrm{g}$ body weight $)$; $\mathbf{\square}-\mathbf{\square}$, cortisol (10 $\mu \mathrm{g} / \mathrm{g}$ body weight) $---\bullet$, thyroidectomized;

-- - $\mathbf{0}$, adrenalectomized (Kumegawa et al.) ${ }^{116)}$.

乳期をはさんだラットの咬筋の生後発達と発達制 御要因について 調べて，興味ある 所見を得てい る。すなわち， ラット咬筋の経時的発達を筋線維 の径と 組織化学的性質の 変化によって解析した 所, 離乳期を前後して, これらは大きく変化して おり，そのパターンは頭蓋骨の頭蓋部と顔面部と の比率の生後発達に似た経過を示す結果を得てい る(Figs. 4 and 5). しかも，頭蓋骨の顔面部の発 達の場合と同様，離乳前の生後初期における咬筋 の発達は甲状腺ホルモンと副腎皮質ホルモンの影 響を受けるが，離乳期が近づくにつれて，両ホル モンの効果は低下し(Figs. 6 and 7), 離乳期以後 は，先ほど書いたように咀嚼作用の影響下にある といら結果が得られた。これらの一連の実験で調 べられたホルモンが，間接的に作用しているの か，またはいずれかの organ に対して直接作用し ているのかは，これまでの実験だけではわからな い。しかし，骨格筋の成長，分化が，このように 内分泌的要因によってコントロールされていると いうデータがあり，しかも，骨格筋に属する咀嚼 筋が顎顔面の成長に重要な 位置をしめるのであれ ば, 咀嚼器官の要素である咀嚼筋の 成長制御要因 として, 内分泌学的立場からの研究は, 今後, ま
すます重要になってくると思われる。そして，こ れらは，すでに述べたような意味から，単独では なく，影顔面と咀嚼筋の発達とを総合的にとらえ る立場から研究されていかなければならない。

\section{3. 唾液腺および一般消化器官 の発達およびその制御要因}

動物が生きていくためには，捕食器官あるいは 咀嚼器官としての䪹顔面の 発達は重要であるが, 生きるという大前提のもとで考えるならば，唾液 腺を含む一般消化器官系の発達がほぼ同期化して おこらなければならない。Schumacher ${ }^{107)}$ は来日 記念講演のなかで，興味ある発言をしている。咀 嚼器官系を構成する 1 つの要素の 久陥は他の咀嚼 器官の欠陥を誘引し，それが原因となって不完全 な咀嚼活動が抗こり，代謝に影響し，結果的には 頭蓋, 顔面の成長に影響するというのである。こ れは, 咀嚼器官系の発達と消化器官系の発達が相 互にかかわりを持つことを示唆するものとして重 要な発言である。とくに，離乳期前後の哺乳類全 般において，両者の発達のバランスがとれていな ければ，正常な全身的成長，発育が望めないこと は容易に予想できることである。そこで，ここで 
Table 1 Body weight and parotid gland amylase activity of adrenalectomized -thyroidectomized 12-day-old rats treated with cortisol and/or L-thyroxine $\left(\mathrm{T}_{4}\right)$ for 5 days (values are means $\pm \mathrm{SD}$ for 6 animals)

\begin{tabular}{|c|c|c|}
\hline Treatment & $\begin{array}{l}\text { Body weight } \\
\text { (g) }\end{array}$ & $\begin{array}{l}\text { Amylase activity } \\
\text { (units/mg protein) }\end{array}$ \\
\hline None (control) & $25.0 \pm 2.68$ & $27.9 \pm 3.94$ \\
\hline Adrenalectomized + thyroidectomized & $24.0 \pm 1.26$ & $28.8 \pm 4.66$ \\
\hline+ cortisol & $25.2 \pm 3.22$ & $25.1 \pm 5.80$ \\
\hline$+\mathrm{T}_{4}$ & $22.9 \pm 2.97$ & $81.1 \pm 3.33^{*}$ \\
\hline$+\mathrm{T}_{4}+$ cortisol & $24.1 \pm 3.07$ & $106.9 \pm 9.10^{*}$ \\
\hline
\end{tabular}

${ }^{*} \mathrm{P}<0.01$ : significantly different from control group by $\mathrm{t}$-test (Kumegawa et al.) ${ }^{116)}$.

は, 唾液腺, 胃, 膵臓らの機能的な面の発達過程 とその制御要因に焦点をあててみる。

Daniels ら ${ }^{108)}$ が小腸の機能的分化とホルモンの 影響に関して興味ある研究を行なった。離乳前の ラット小腸の高分子物質の吸収能力を分子量が 160000 の polyvinyl pyrrolidone (PVP) の小腸 からの取込みで調べたところ，この能力はコント ロール群では離乳期の 20 日頃まで続き，その後消 失することを発見した。これは，生後母乳を吸う 哺乳類にとって重要なことで，初乳に含まれる母 体からの高分子の抗体は腸壁の持つ初期のこの能 力によって吸収される。そして，この能力の消長 に副腎皮質ホルモンが関与しており，しかもホル モンに感作する時期が決まっていることがラット の実験によって明らかにされている。これは，内 分泌現象と消化器官系の発達との 重要なかかわり を示唆するものである。

ここで, 再び全体的視野に立って咀嚼器官系と 消化器官系の生後発達について考えてみると，動 物が生きるためという合目性によって，これらの 器官が，ほぼ同期化して発達していくためには， 発達の制御機構が全く異なる要因よりは，共通の 要因で制御されている方が好都合であると思われ る。

そこで, 咀嚼器官および消化器官系の重要な形 質の転換がおこる時期として位置づけられ，哺乳 類に共通な現象である離乳期を中心に，発達制御 要因に共通性があるかどうかについて話を進め る。

例えば，唾液腺のアミラーゼは，母乳を飲んで いる時期には必要ではないが, diet が炭水化物の
含有率の高いものへと転換する 離乳期に活性が上 昇してくる。この離乳期とアミラーゼ活性の上昇 との因果関係や制御機構に関する研究は, Hall と Schneyer ${ }^{109,110)}$ および Johnson と Sreebny $ら^{111,112)}$ の耳下腺の研究によって口火が切られた ようである。彼らは, diet の転換がアミラーゼ活 性の上昇と関係があるという結果を得ているが, 離乳がスムースに進行するためには，固型物を食 ベる時にアミラーゼ活性は上昇していなければな らず，したがって， diet の転換による制御だけで は説明しきれない。

その結果, 胎生期および生後の動物の器官構造 に影響を与えることで知られる副腎皮質ホルモン に，やはり目が向けられた。Takeuchi ら ${ }^{113)}$ は, ラットで，Takuma ら ${ }^{114)}$ はマウスで副腎皮質ホ ルモンが耳下腺のアミラーゼ活性の誘導の制御に 関与していることを確めた。このホルモンの影響 は形態的にも認められた（Fig. 8)。なお， Kumegawa ら ${ }^{115)}$ は，インシュリンおよびサイロキシン が，その効果を増大させることをin vitro の実験 で確認している。Kumegawa ら ${ }^{116)}$ は，副腎皮質 ホルモンと甲状腺ホルモン，および solid diet が， 発育途上にある幼若ラットの耳下腺アミラーゼ活 性の誘導とどのような関係を持つのかを，甲状腺 および副腎を摘出したラットで調べた。その結 果，甲状腺ホルモンと副腎皮質ホルモンが離乳期 前のラットの耳下腺のアミラーゼ活性を早期に誘 導することを証明した (Fig. 9)。そして，両者の ホルモンの間には働きの上で違いがあることを認 めた。すなわち, 甲状腺ホルモンは単独で作用す るが，副腎皮質ホルモンは，エンドジーナスな甲 


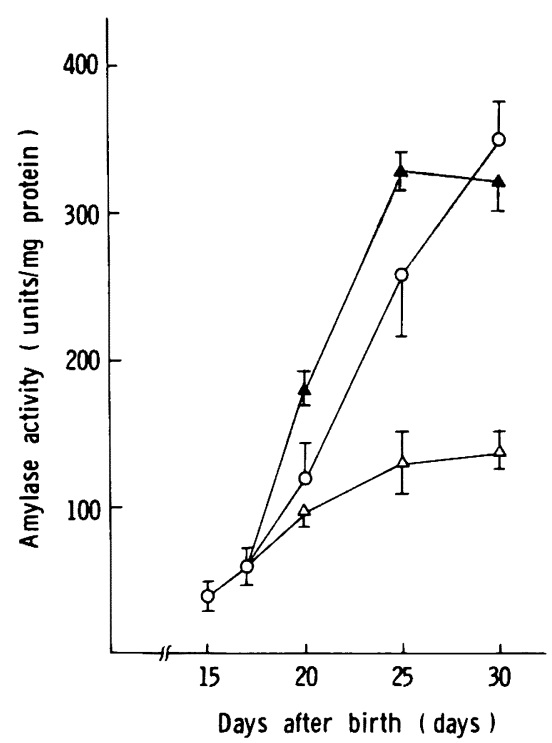

Fig. 10 Effect of diet on rat parotid gland amylase activity. Values are means $\pm S D$ for six animals. $O$, control (normal weaning); $\Delta$, milk only ; $\boldsymbol{\Delta}$, solid diet from day 17 (Kumegawa et al.) ${ }^{116}$.

状腺ホルモンの存在下でアミラーゼ活性の早期誘 導に効果を示した（Table 1)。そして，正常群で のアミラーゼ活性の上昇およびホルモン投与効果 の有効な時期に注目すると, 先に述べた咀嚼器官 系の発達に対する効果よりもやや授乳期の後半に ずれこんでいることがわかる (Figs. 2 and 9)。 この時間的ずれは，きたるべき離乳にそなえて， 固型の餌を効率よく取り込むため, 咀嚼器官の発 達をまず刺激し，ひき続き消化器官系を発達させ るという，哺乳類一般に適用しうる咀嚼器官の発 達の 適応様式の 結果といらことができる。さら に, solid diet は, やはり離乳期にかけての耳下 腺アミラーゼの誘導に対して有効であった（Figs. 10 and 11$)^{116,117)}$ 。

では, 他の消化器官の発達と制御要因について はどうであろうか。例えば膵臟についてみると， これまで色々な動物を用い多くの研究がなされて いる ${ }^{113,115,118-120)}$ 。そして, それらの多くが, やはり 副腎皮質ホルモンの重要性を強調している。しか しながら，ラットやマウスにおいて，副腎皮質ホ ルモンは離乳期前後の血中レベルの 変化が少ない ため, 授乳期中期から離乳期初期にかけて血中レ

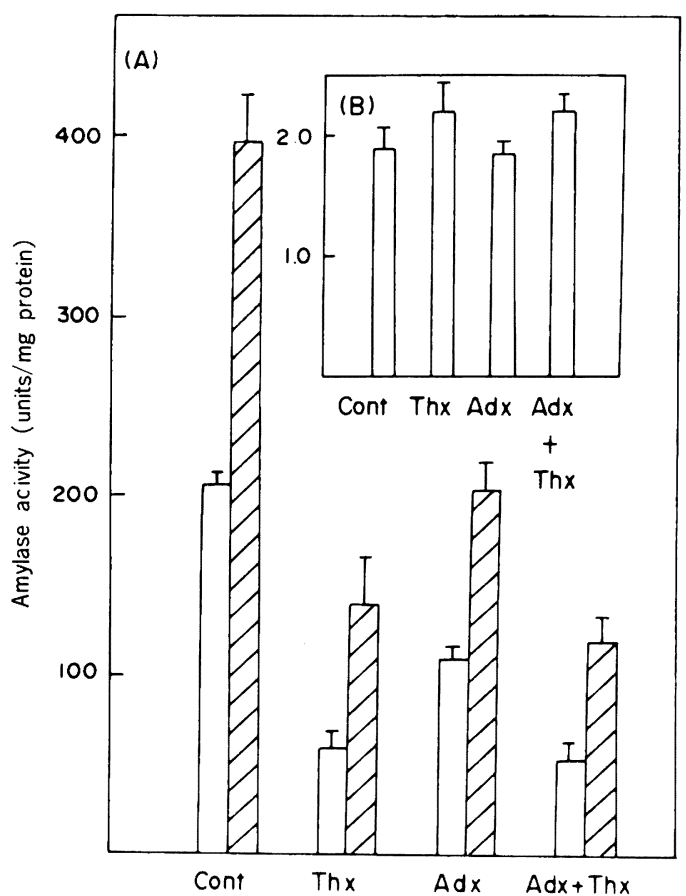

Fig. 11 Influence of feeding solid diet on the induction of amylase activity in thyroidectomized ( $\mathrm{T} \mathbf{x})$ and/or adrenalectomized (Adx) rats. The bars represent mea$\mathrm{ns} \pm \mathrm{SD}$ six animals. Animals were given a solid diet for 9 days before killing (hatched columns). The open columns represent animals on ordinary feeding. Insert (B) represents the ratio between solid diet and ordinary feeding (Kumegawa et al. $)^{117)}$.

ベルの上昇してくる甲状腺ホルモンに目が向けら れた ${ }^{121-123)}$ 。Kumegawa ら ${ }^{124)}$ は in vitro で, ニワ トリの膵藏のアミラーゼの誘導に, 甲状腺ホルモ ンとインシュリンが必要なことを確かめ, つい で，ラットにおいても，甲状腺ホルモンと副腎皮 質ホルモンが，膵臟のアミラーゼ活性の早期誘導 に permissive effect を持つことを明らかにした $(\text { Table } 2)^{125)}$ 。さらに, 胃についてもこれらのこ とが確められた。それによると，コントロールの ラットのペプシノーゲンの量は, ほぼ耳下腺のア ミラーゼと同じ時期に上昇し，その上昇には，甲 状腺ホルモンと副腎皮質ホルモンが，やはり permissive effect を持っていた (Table 3) ${ }^{126)}$ 。マウ スでは, 両者のホルモンが additive effect を示す といら点では異なっていた。そして，マウスにお 
Table 3 Mean $( \pm \mathrm{SD})$ activity of stomach pepsinogen in groups of six intact rats treated with cortisol (10 $\mu \mathrm{g} / \mathrm{g}$ body weight) and/or L-thyroxine ( $\mathrm{T}_{4} ; 0.2 \mu \mathrm{g} / \mathrm{g}$ body weight) starting on the day indicated for 5 days when values were determined

\begin{tabular}{lccccc}
\hline \multirow{2}{*}{ Treatment } & \multicolumn{5}{c}{ Pepsinogen activity (units/mg protein) } \\
\cline { 2 - 6 } & Day 1 & Day 5 & Day 10 & Day 15 & Day 20 \\
\hline control & $2.14 \pm 0.18$ & $2.07 \pm 0.26$ & $2.48 \pm 0.31$ & $9.32 \pm 1.13$ & $18.8 \pm 2.28$ \\
cortisol & $2.36 \pm 0.08$ & $4.51 \pm 0.57^{*}$ & $5.86 \pm 0.35^{*}$ & $21.6 \pm 1.40^{* *}$ & $21.0 \pm 1.86$ \\
$\mathrm{~T}_{4}$ & $2.01 \pm 0.16$ & $1.94 \pm 0.12$ & $3.05 \pm 0.49$ & $10.9 \pm 0.62$ & $18.6 \pm 1.62$ \\
cortisol $+\mathrm{T}_{4}$ & $3.15 \pm 0.09^{*}$ & $5.79 \pm 0.32^{* *}$ & $7.61 \pm 0.55^{*}$ & $22.8 \pm 3.45^{* *}$ & $22.1 \pm 3.87$ \\
\hline
\end{tabular}

${ }^{*} \mathrm{P}<0.05 ;{ }^{* *} \mathrm{P}<0.01$ : compared with control values (t-test) (Kumegawa et al.) ${ }^{126)}$.

Table 2 Mean \pm SD of pancreatic amylase activity in six thyroidectomized, adrenalectomized 12 -day-old rats treated with cortisol $(10 \mu \mathrm{g} / \mathrm{g}$ body $\mathrm{wt})$ and/or L-thyroxine ( $\mathrm{T}_{4}: 0.2$ $\mu \mathrm{g} / \mathrm{g}$ body $w \mathrm{t}$ ) for 5 days starting 2 days after the operations

\begin{tabular}{|c|c|}
\hline Treatment & $\begin{array}{l}\text { Amylase activity } \\
\text { (units/mg protein) }\end{array}$ \\
\hline None (control) & $42.2 \pm 5.36$ \\
\hline \multicolumn{2}{|c|}{$\begin{array}{l}\text { Adrenalectomized }+ \\
\text { thyroidectomized }\end{array}$} \\
\hline No hormones & $42.5 \pm 7.39$ \\
\hline Cortisol & $52.0 \pm 4.46^{*}$ \\
\hline$T_{4}$ & $45.1 \pm 8.36$ \\
\hline Cortisol $+\mathrm{T}_{4}$ & $49.0 \pm 13.8^{* *}$ \\
\hline \multicolumn{2}{|c|}{$\begin{array}{l}* \mathrm{P}<0.05 ; * * \mathrm{P}<0.001: \text { significantly different } \\
\text { from control gronp by } \mathrm{t} \text {-test (Kumegawa et } \\
\text { al.) }{ }^{12.5)} \text {. }\end{array}$} \\
\hline \multicolumn{2}{|c|}{$\begin{array}{l}\text { いては，これらのホルモンの影響は形態的にも確 } \\
\text { かめられている (Fig. 12)。 }\end{array}$} \\
\hline \multicolumn{2}{|c|}{ ここで興味深いのは，咀嚼器官系と消化器官系 } \\
\hline \multicolumn{2}{|c|}{$\begin{array}{l}\text { 時期に主要な転換をしていることである。しか } \\
\text { も，それぞれが共通の制御要因によって，少しづ } \\
\text { つ条件を変えながらコントロールされている結果 }\end{array}$} \\
\hline \multirow{2}{*}{\multicolumn{2}{|c|}{$\begin{array}{l}\text { をみると，その合理性は驚くばかりであるが，そ } \\
\text { れだけに，これらのうちの要素の一つの発達阻害 } \\
\text { がひきおこす伦険性は計り知れない。 }\end{array}$}} \\
\hline & \\
\hline これらに加えて, & \\
\hline
\end{tabular}

顎下腺等を用いて，多くの研究者が，そこに含ま れる物質とその性差, およびそれらの誘導機構 について研究し，すぐれた総説が数編でてい

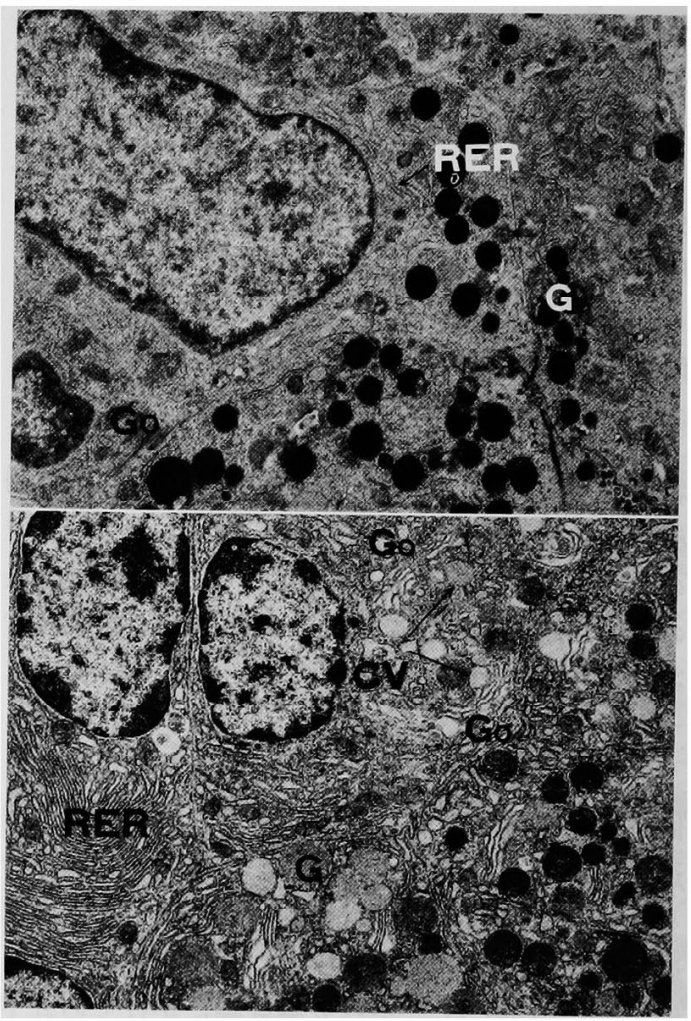

Fig. 12 Electron micrograph of chief cells in the stomach of untreated mice on day 10 (Top). The chief cells contain little rough surface endoplasmic reticulum (RER) or Golgi apparatus (Go). Small granules $(G)$ are seen in these cells. $\times 12,000$. Electron micrograph of chief cells in the stomach of mice on day 10 after daily injections of hydrocortisone plus thyroxine for 5 days. (Bottom) The Golgi apparatus (Go) and rough surface endoplasmic reticulum (RER) are well developed. Large granules (G) and condensed vacules (CV) are clearly seen. $\times 12,000$. (Kumegawa et al. $)^{127)}$. 


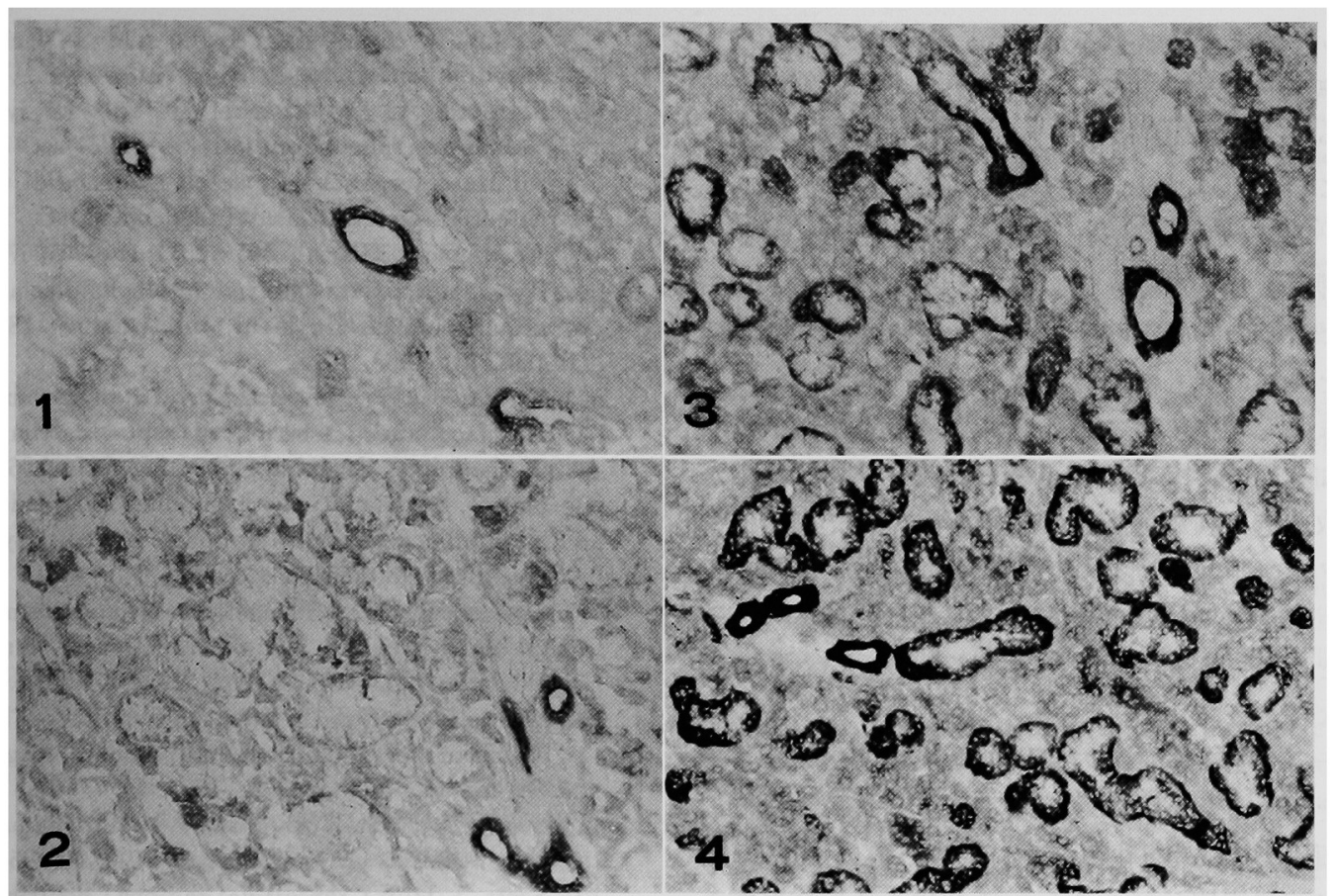

Fig. 13 Light micrographs of mouse submandibular glands from sections tested forG-6-PDH activity. 1, Intact female mouse. Enzyme activity is detected only in the excretory ducts; 2, Intact male mouse. Slight, but distinct activity is observed at the periphery of the convoluted tubules; 3, After DHT-injection into female mice for 3 days. Moderate activity is seen in the convoluted tubules; 4, After $\mathrm{T}_{4}$-injection into female mice for 3 days. The tubules show distinct activity. No remarkable change in acinar cells is seen. $\times 40$. (Tajima et al. $)^{130)}$.

る $^{128,129)}$ 。そのうちの1つで, 分泌細管部の発達を G-6-PDH の活性でみたものでは，コントロー ル群では, やはり離乳期以後に成体型に 移行し， この早期誘導には甲状腺ホルモンと性ホルモンで ある男性 ホルモン等が関与していることが示され た (Fig. 13) ${ }^{130)}$ 。しかしながら，このような研 究が今回の課題とどのように関係していくかは今 後の問題である。

\section{4.おわりに}

咀嚼器官および消化器官は生命を 維持するのに 必要なエネルギーを得るための最も基本的な要素 である。この重要な器官群の生後発達とその制御 要因について，これまでの研究の主な流れをまと めてみると，以下のようになる。1) 遺伝的要因 の研究，2）個体新生要因の研究，3）環境要因 の研究, 4) functioal matrix の研究，5) 内分 泌要因の研究，6) 隣り合う，あるいはそうでな
い器官の成長が互いにバランスのとれた相関性の あるものとして進行するという相対成長諭的立場 からの研究。1）～6）までの研究は，すでに紹 介したように単独で研究されている場合もあり, 複合的に研究されている場合もあるが，あらゆる 角度からの対応が必要とされる現代の歯科医療に 十分活用できるほどには総合的な基礎研究がおこ なわれていないようである。

すでに述べたことからでもわかるように，動物 の体の成長は，おそらくすべてがプログラムされ ており，それは時間の経過とともに連続的におき ていくため，今後は，成長期に刻々と進行する咀 嚼, 消化器官の各要素の変化の正確な把握と相対 関係，およびその変化に対応した制御要因につい ての総合的かつ統合的研究が求められることにな るだろう。このような意味では，6）の立場から のアプローチは重要である。さらに, 内分泌的要 因，および他の内在的要因に関する研究は，今後 
もっと桩大される必要がある。1 例を上げれば, 近年 $\mathrm{EGF}$ が，母乳，羊水，ヒトの血液などに見

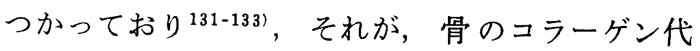
謝に関与することが最近報告されている511。しか も, EGF の in vivo における発現にホルモンが 制御因子として関与しているという ${ }^{1291}$ ，まさに三 つどもえの関倸などは，上記のような研究の必要 性を裏づけるものである。

また，すでに述べたように，食物の物理的性状 による影響ではなく，食物に含まれ経口的に外か ら取り込まれる可能性のある物質，例えば活性型 ビタミンD が骨形成を促進するという研究結果 等 ${ }^{53)}$ をると, 今後の研究は, 歯学, 医学という 枠をこえて生物学一般への対応を迫まられること になりそうである。

一方, 咀嚼器官等の個体発生, 発達に対する理 解を深めるためには, 系統発生的研究, 例えば, 魚類 ${ }^{134-136)}$ から哺乳類へという種の違いのなかで, 顎口腔機能等がどのような系統進化的適応形態を とってきたかについての生物学的研究等も, 重要 な今後の課題である。そして, これらの十分な理 解が, われわれ人類の口腔機能をより深く理解寸 る助けとなるであろう。

なお, 本研究の一部は以下の文部省科学研究費の補助 によって行なわれた。一般研究 C, 総合研究 $\mathrm{A}$ : 唾液腺 の発生と分化，昭和 $52 ， 53$ 年，炤和 $54 ， 55$ 年（代表，久 米川正好), 奖励研究 A : 顎下腺腺状部細胞における男 性ホルモンと甲状腺ホルモンの相互作用，昭和53，54年 (田隈泰信), 咀緭器官の生後発達に対するホルモンと咀 嚼作用の影響および相対成長の解析，昭和56，57，59年 (前田憲彦) 特定研究：生物の適応戦略と社会構造, 昭 和58,59年 (分担, 前田霓彦)。

\section{文献}

1) Limborgh, J. van der: A new view on the control of the morphogenesis of the skull. Acta Morph. Neerl. Scand. 8 : 143-160, 1970.

2) Weinmann, J. P. and Sicher H. : Bone and Bones, 2nd ed., p. 92, C.V. Mosby Co., St. Luis, 1955.

3) Limborgh, J. van der and Verwoerd-Verhoef, H. L.: Effects of artificial unilateral facial clefts on growth of the skull in young rabbits. J. Dent. Res. 47 : 1013, 1968

4) Scott, J. H.: The cartilage of the nasal septum. A contribution to the study of facial growth. Brit. Dent. J. 95 : 37-43, 1953.

5) Petrovic, A. and Charlier J. P.: La synchondrose sphenooccipital de june rat en culture $d^{\prime}$ organes: mise en evidence $d^{\prime}$ un potential de croissance independent. C. R. Acad. Soc. (Paris) $265:$ 1511-1513, 1967.

6) Baume, L. J.: Patterns of cephalofacial growth and development. Int. Dent. J. 18 : 489-513, 1968.

7) Sarnat, B. G. : Postnatal growth of the nose and face after resection of septal cartilage in the rabit. Oral Surg. $26: 712-727,1968$.

8) Sarnat, B. G. : Growth of bones as revealed by implant markers in animals. Am. J. Phys. Anthrop. 29 : 255-286, 1968.

9) Latham, R. A. : The sella point and postnatal growth of the human cranial base. Am. J. Orthodont. 61 : 156-162, 1972.

10) Hinrichsen, G. J. and Storey, E. : The effect of force on bone and bones. Angle Orthodont. 38 : 155-165, 1963.

11) Scott, J. H.: The growth of the human face. Proc. Roy. Soc. Med. 47 : 91-100, 1954.

12) Scott, J. H. : Craniofacial regions; contribution to the study of the facial growth. Dent. Pract. 5 : 208-214, 1955.

13) Scott, J. H. : Growth at facial sutures. Am. J. Orthodont. 42 : 381-387, 1956.

14) Scott J. H.: The analysis of facial growth. Part I. The anteroposterior and vertical dimensions. Am. J. Orthodont. 44 : 507-512, 1958.

15) Ford, E. H. R. : Growth of the human cranial base. Am. J. Orthodont. $44: 498-506$, 1958.

16) Ackerman, J. L., Takagi, Y., Proffit W. R. and Baer, M. J.: Craniofacial growth and development in cebocephalia. Oral Surg. 19: 543-554, 1965.

17) Latham, R. A.: Mechanism of maxillary growth in human cyclops. J. Dent. Res. 50: 929-933, 1971.

18) Moss, M. L. and Greenberg, S. N. : Postnatal growth of the human skull base. Angle Orthodont. 25: 77-84, 1955.

19) Moss, M. L. : Inhibition and stimulation of suture fusion in the rat carvaria. Anat. Rec. 136 : 457-468, 1960.

20) Moss, M. L. : The functional matrix : In : Vistas in Orthodontics (edited by Kraus, R. S. and Riedel, R. A.), Lea \& Febiger, Philadelphia, p 85-98, 1962.

21) Klaauw, C. J. van der: Cerebral skull and facial skull. A contribution to the knowledge of skull structure. Arch. Neerl. Zool. 9: 16- 
36, 1946.

22) Klaauw, C. J. van der : Size and position of the functional components of the skull. A contribution to the knowledge of the architecture of the skull, based on data in the literature. Arch. Neerl. Zool. 9 : 1-176, 1948.

23) Klaauw, C. J. van der: Size and position of the functional components of the skull (contrinuation), Arch. Neerl. Zool. 177-368, 1951.

24) Klaauw, C. J. van der: Size and position of the functional components of the skull (conclusion). Arch. Neerl. Zool. 9 : 369-335, 1968.

25) Hunter, W. S. and Enlow, D. H.: The growth of the face in relation to the cranial base. Trans. Europ. Soc. Orth. Rep. 44 : 321335, 1968.

26) Moss, M. L. : The primacy of functional matrices in orofacial growth. Dent. Pract. 19 : 65-73, 1968.

27) Horowitz, S. L. and Shapiro, H. H. : Modifications of mandibular architecture following removal of temporalis muscle in the rat. J. Dent. Res. 30 : 276-280, 1951.

28) Horowitz, S. L. and Shapiro H. H. : Modification of skull and jaw architecture following removal of the masseter muscle in the rat. Am. J. Phys. Anthrop. 13 : 301-308, 1955.

29) Avis, V.: The relation of the temporal muscle to the form of coronoid process. Am. J. Phys. Anthrop. $17:$ 99-104, 1959.

30) Avis, V.: The significance of the angle of the mandibule: an experimental and comparative study. Am. J. Phys. Anthrop. 19 : 55-61, 1961.

31) Boyd, T. G., Castelli, W. A. and Huelke, D. F. : Removal of the temporalis muscle from its origin: Effects on the size and shape of the coronoid process. J. Dent. Res. 46 : 997-1001, 1967.

32) Shumacher, G. H. : The maxillo-mandibular apparatus in the light of experimental investigations. In : Morphology of the Maxillo -Mandibular Apparatus. VEB George Thieme, Leipzig, p 13-35, 1972.

33) Soni, N. N. and Malloy, R. B. : Effect of removal of the temporalis muscle on the coronoid process in guinea pigs; Ouantitative triple fluorochrome study. J. Dent. Res. 53 : 474-480, 1974

34) Madeira, M. C. Oliveira, J. A., Matheus, M. T. G. and Watanabe II -sei : Radiographic changes in the trabecular pattern of the mandibular ramus following masseterectomy in growing monkey (Cebus apella). J. Dent.
Res. 56 : 543, 1977.

35) Behrents, R. G.: The influence of the trigeminal nerve on facial growth and development. M. S. Thesis, Case Western Reserve Universty, Cleveland, 1975.

36) Kikuchi, M., Lu, C.-H., Sebata, M. and Yamamoto, Y.: The mandibular development of the rat after the denervation of the masseteric nerve. Bull. Tokyo Dent. Coll. 19 : 75-86, 1978.

37) Gardner, D. E., Luschei, E. S. and Joondeph, D. R.: Alterlations in the facial skeleton of the guinea pig following a lesion of the trigeminal motor muscles. Am. J. Orthodont. $78: 66-80,1980$.

38) Koski, K. and Rönning, O.: Pitkän luun rustiosen pään siirännäisen kasvupotentiaalista rotalla. Suom. Hammaslääk. Toim. 62 : 165169, 1966.

39) Koski, K. and Rönning, O. : Growth potential of transplanted components of the mandibular ramus of the rat Suom. Hammaslääk. Toim. 61 : 292-297, 1965.

40) Rönning, O. : Observations on the intracerebral transplantation of the mandibular condyle. Acta Odont. Scand. 24 : 443-457, 1966.

41) Koski, K.: Cranial growth centers, facts or fallacies? Am. J. Orthodont. 54:566583, 1968.

42) Koski, K. and Rönning, O. : Intracerebral isologus transplantion of the condylar cartilage with and without the articular disc. Am. J. Orthodont. 60 : 86, 1971.

43) Scammon, R. E., Harris, J. A., Jackson C. M. and Patterson, D. G. : The measurement of man. University of Minesota Press Mi. nneapolis, 1930.

44) Maeda, N., Amano, H., Machino, M., Kaneko, T. and Kumegawa, M.: L.Thyroxine, cortisol, and diet affect the potsnatal development of the facial part of the skull in developing rats. Anant. Anz. (in press).

45) Moss, M. L. : Functional analysis of the coronid process in the rat. Acta Anat. 77 : 11-24, 1970.

46) Moss, M. L. : Functional cranial analysis of the mandibular angular cartilage in the rat. Angle Orthodont. 39 : 209-214, 1969.

47) Krogman, W. M. : Principles of human growth. Ciba Sympos. 5 : 1458-1466, 1943.

48) Spiegel, R. N., Sather, A. H. and Hayles, A. B.: Cephalometric study of children with various endocrine diseases. Am. J. Orthodont. 59 : 362-375, 1971.

49）前田憲彦, 花井 汎, 久米川正好：ラットにお け石咀嚼器官の生後分化に関する研究 (3) 幼 
若ラットの M. masseter superficialis を構成 する筋線維の径および ATPase 活性に対する ホルモンの影響, 城歯大紀要 $8:$ 139-142, 1979.

50) Haneji, T., Kurihara N., Ikeda, K. and Kumegawa, M. : I $\alpha$, 25-Dihydroxyvitamine $\mathrm{D}_{3}$ and analogues of vitamin $\mathrm{D}_{3}$ induce alkaline phosphotase activity in osteoblastic cells derived from newborn mouse calvaria. J. Biochem. 94 : 1127-1132, 1983.

51) Kumegawa, M., Hiramatsu, M., Hatakeyama, K., Yajima, T., Kodama, H., Osaki, T. and Kurisu, K. : Effects of epidermal growth factor on osteoblastic cells in vitro. Calcif. Tissue Int. 35 : 542-548, 1983.

52) Kumegawa, M. Ikeda, E., Tanaka, S., Haneji, T., Yora, T., Sakagishi, Y., Minami, N. and Hiramatsu, M. : The effects of prostaglandin $\mathrm{E}_{2}$, parathyroid hormone, 1, 25-dihydroxycholecalciferol, and cyclic nucleotide analogs on alkaline phosphatase activity in osteoblastic cells. Calcif. Tissue Int. 36 : 7276, 1984 .

53) Kurihara, N., Ikeda, K., Hakeda, Y., Tsunoi, M., Maeda, N. and Kumegawa, M. : Effect of 1, 25-dihydroxyvitamine $\mathrm{D}_{3}$ on alkaline phosphotase activity and collagen synthesis in osteoblastic cells clone MC3T3E1. Biochem. Biophys. Res. Commun. 119 : 767-771, 1984.

54) Partanen, A. M., Thesleff, I. and Ekblom,P. : Transferrin is required for early tooth morphogenesis. Differentiation 27 : 59-66, 1984.

55) Tsunoi, M., Hakeda, Y., Kurihara, N., Maeda, N., Utumi, N. and Kumegawa, M. : Effect of transferrin on alkaline phosphatase activity and collagen synthesis in osteoblastic cells derived from newborn mouse calvaria. Exp. Cell Res. 153 : 240-244, 1984.

56) Shafiq, S. A., Gorycki, M., Goldstone, L. and Milhorat, A. T.: Fine structure of fiber types in normal human muscle. Anat. Rec. 156 : 283-302, 1966.

57) Edgerton, V. R. and Simpson, D. R. : The intermediate muscle fiber of rats and guinea. pigs. J. Histochem. Cytochem. 17 : 823-838, 1969.

58) Barnard, R. J., Edgerton, V. R., Furukawa, T. and Peter, J. B. : Histochemical, biochemical, and contractile properties of red, white, and intermediate fibers. Am. J. Physiol. 220 : 410-414, 1971.

59) Burke, R. E., Levine, D. N., Tsairis, P. and Zajac, F. E. : Physiological types and histochemical profiles in motor units of the cat gastrocnemius. J. Physiol. 234:723-748, 1973.

60) Hancock, J.: Studies of grazing behaviour in relation to grassland management. I. Variations in grazing habits of dairy cattle. J. Agric. Sci. 44 : 420-433, 1954.

61) Wachstein, M. and Meisel, E. : The distribution of histochemically demonstrable succinic dehydrogenase and mitochondria in tongue and skeletal muscles. J. Biophys. Biochem. Cytol. 1 : 483-489, 1955.

62) Gordon, J. G. : The act of rumination. J. Agric. Sci. 50 : 34-42, 1958.

63) Swanson, E. W. and Harris, Jr. J. D. : Development of rumination in the young calf. J. Dairy Sci. 41 : 1768-1776, 1958.

64) Tsukamoto, S. and Mori, M.: Distribution of muscle fibers of three types differentiated by succinic dehyrogenase activity in the skeletal muscle. Arch. Histol. Jpn. 26 : 329-339, 1966.

65) Suzuki, A. : Histochemical classification of individual skeletal muscle fibers in the sheep. I. On $M$. semitendinosus, $M$. longissimus dorsi, M. psoas major, $M$. latissimus dorsi and M. gastrocnemius. Jpn. J. Zootech. Sci. 42 : 39-54, 1971.

66) Suzuki, A.: Histochemical classification of individual skeletal muscle fibers in the sheep. III. On the $M$. masseter. Ipn. J. Zootech. Sci. 43 : 161-166, 1972.

67) Ringqvist, M. : Histchemical enzyme profiles of fibers in human masseter muscles with special regard to fibers with intermediate myofibriller ATPase reaction. J. Neurol. Sci. 18 : 133-141, 1973.

68) Suzuki, A.: A comparative histochemical study of the masseter muscle of the cattle, sheep, swine, dog, guinea pig, and rat. Histochemistry 51: 121-131, 1977.

69) Hiraiwa, T.: Histochemical properties of masticatory muscles of growing rat and of matured mammals. Comp. Biochem. Physiol. 59A : 231-238, 1978.

70) 町野 守, 前田憲彦, 増田 屯, 久米川正好: マウス咀嚼筋の生後発達の 研究, 城歯大紀要 10 : 111-116, 1981.

71) Maeda, N., Hanai, H. and Kumegawa, M. : Postnatal development of masticatory organs in rats. I. Consecutive changes in histochemical properties and diameter of muscle fibers of the $M$. masseter superficialis. Anat. Anz. 149 : 319-328, 1981.

72) Takasu, T. and Hughes, B. P. : Lactate dehydrogenae isozyme patterns in human skeletal muscle. Part II. Changes of isozyme pattern in ontogeny. J. Neurosurg. Psychiat. 32 : 175-179, 1969.

73) Dubowitz, V. and Pearse, A. G. E. : A 
comparative histochemical study of oxidative enzyme and phospholyase activity in skeletal muscle. Histochemie 2 : 105-117, 1960.

74) Gauthier, G. F. and Padykula, H. A. : Cytochemical studies of fiber types in skeletal muscle. A compartive study of the mammalian diaphragm. J. Cell Biol. 28 : 333-354, 1966.

75) Edgerton, V. R. and Sympson, D. R. : The intermediate muscle fiber of rats and guinea pigs. J. Histochem. Cytochem. 17 : 828-838, 1969.

76) Ashmore, C. R. and Doerr, L. : Comparative aspects of muscle fiber types in different species. Exp. Neurol. 31: 408-418, 1971.

77) Davis, A. S. and Gunn, H. M. : A com. parative histochemical study of the mammalian diaphragm and $\mathrm{m}$. semitendinosus. J. Anat. 110 : 137-139, 1971.

78) Buller, A. J., Eccles, J. C. and Eccles, R. M. : Interactions between motoneurons and muscle in respect of the characteristic speeds of their responses. J. Physiol. 150 : 417-439, 1960.

79) Close, R. : Effects of cross-union of motor nerves to fast and slow skeletal muscle. $\mathrm{Na}$ ture 206 : 831, 1965.

80) Dubowitz, V.: Cross-innervated mammalian skeletal muscle: histochemical, physiological and biochemical observations. J. Physiol. 193 : 481-496, 1967.

81) Dubowitz, V. and Newman, D. L. : Changes in enzyme pattern after cross-innervation of fast and slow skeletal muscle. Nature 214 : 840-841, 1967.

82) Karpti, G. and Engel, W. K. : Neuronal trophic function. A new aspect demonstrated histochemically in developing soleus muscle. Arch. Neurol. 17 : 542-545, 1967.

83) Kugerberg, E. : Adaptive transformation of rat soleus motor units during growth. J. Neurol. Sci. 27 : 269-289, 1976.

84) Niederle, B. and Mayr, R. : Course of denervation atrophy in Type I and Type II fibers of rat extensor digitorum longus $\mathrm{mu}$. scle. Anat. Embryol. 153 : 9-21, 1978.

85) Rubinstein, N., Mabuchi, K., Pepe, F., Salmon, S., Gergely, J. and Sreter, F. : Use of type-specific antimyosin to demonstrate the transformation of individual fibers in chronically stimulated rabbit fast muscles. J. Cell Biol. 79 : 252-261, 1978.

86) Zelená, J.: The morphogenetic influence of innervation on the ontogenetic development of muscle spindle. J. Embryol. Exp. Morphol. 5 : 283-292, 1957.
87) Zelená, J.: The role of sensory innervation in the development of mechanoreceptors. Prog. Brain Res. 43 : 59-64, 1976.

88) Schiaffino, S. and Pierobon Bormioli, S. : Morphogenesis of rat muscle spindles after nerve lesion during early postnatal development. J. Neurocytol. 5 : 319-336, 1976.

89) Kubota, K. and Masegi, T.: Muscle spindle distribution in snout musculature of the Japan. ese shrew-mole. Anat. Rec. 172 : 703-710, 1972.

90) Kubota, K. and Masegi, T. : Muscle spindle distribution in the masticatory muscle of the Japanese shrew-mole. J. Dent. Res. 51 : 1080-1091, 1972.

91) Kubota, K., Masegi, T. and Osanai, K. : Muscle spindle distribution in masticatory muscles involved in jaw movement. I. Insectivores and lower primates. Acta Anat. Nippon $48: 73,1973$

92) Kubota, K. and Masegi, T. and Osanai, K. : Muscle spindle distribution in the maticatory muscle of Temminck's mole, Mogera wogura (Temminck, 1942). Anat. Rec. 179 : 375-384, 1974.

93) Kubota, K., Masegi, T. and Quanbunchan, K. : Muscle spindle ditribution in masticatory muscle of the tree shrew. J. Dent. Res. 53 : 538-546, 1974.

94) 窪田金次郎：霊長類の咀嚼器官の系統比較研究 一顎運動制御機構を中心として一, 生物科学 33 : 70-77, 1981.

95）井関八郎，季 孟修，窪田金次郎：眼窩下神経 切断後の頻筋の超微細構造, 顎研年次報告 $\mathrm{p}$ 12-14, 1982

96) Holloszy, J. O.: Biochemical adaptaion in muscle. Effects of exercise on mitochondrial oxygen uptake and respiratory enzyme activity in skeletal. J. Biol. Chem. 242: 22782282, 1967

97) Edgerton, V. R., Gerchman, L. and Carrow, R. : Histochemical changes in rat skeletal muscle after exercise. Exp. Neurol. 24 : 110123, 1969.

98) Gollnick, P. D. and King, D. W. : Effect of exercise and training on mitochondria of rat skeletal muscle. Am. J. Physiol. 216 : 1502-1509, 1969.

99) Kowalski, K., Gordon, E. E., Martinez, A. and Adawek, J. : Changes in enzyme activities of various muscle fiber types induced by different exercises. J. Hitochem. Cytochem. $17:$ 601-607, 1969.

100) Barnard, R. J., Edgerton, V. R. and Peter, J. B. : Effect of exercise on skeletal muscle. 1. Biochemical and histochemical proper- 
ties. J. Appl. Physiol. 28 : 762-766, 1971.

101) Ingjer, F. : Effects of endurance training on muscle fiber ATPase activity, capillary supply and mitochondrial content in man. J. Physiol. 294 : 419-432, 1979.

102) Maeda, N., Hanai, H. and Kumegawa, M. : Postnatal development of masticatory organs in rats. III. Effect of mastication on the postnatal development of the $M$. masseter superficialis. Anat. Anz. 150 : 424-427, 1981.

103) Maxwell, L. C., McNamara, J. A., Carlson, D. S. and Faulkner, J. A.: Histochemistry of fibers of masseter and temporalis muscles of edentulous monkeys Macaca mulatta. Archs. Oral Biol. 25 : 87-93, 1980.

104) Kubista, V., Kubistova, J. and Pette, D. : Thyroid hormone induced changes in the enzyme activity pattern of energy-supplying metabolism of fast (white), slow (red), and heart muscle of the rat. Eur. J. Biochem. 18 : 553-560, 1971.

105) Gutmann, E.: Problems in differentiating trophic relationships between nerve and muscle cells. In: Motor Innervation of Muscle (edited by Thesleff, S.), Academic Press, New York, p 323-343, 1976.

106) Maeda, N., Hanai, N. and Kumegawa, M. : Postnatal developmnet of masticatory organs in rats. II . Effects of hormones on the postnatal development of $M$. masseter superficialis. Anat. Anz. 149 : 425-436, 1981.

107) Schumacher, G. H. : 頭蓋顔面の成長に関す る2, 3 の結果と問題点. 国際歯科ジャーナル 2 : 735-741, 1975.

108) Daniels, V. G., Hardy, R. N. and Malinowska, K. W.: The effect of adrenalectomy or pharmacological inhibition of adrenocortical function on macromolecule uptake by the new-born rat intestine. J. Physiol. 229 : 697707, 1973.

109) Hall, H. D. and Schneyer, C. A. : Salivary gland atrophy in rat induced by liquid diet. Proc. Soc. Exp. Biol. Med. 117 : 789-793, 1964.

110) Hall, H. D. and Schneyer, C. A.: Physiological activity and regulation of growth of developing parotid. Proc. Soc. Exp. Biol. Med. 131 : 1288-1291, 1969.

111) Sreebny, L. M. and Johnson, D. A. : Effect of food consistency and decreased food intake on rat parotid and pancreas. Am. J. Physiol. 216 : 455-460, 1968.

112) Sreebny, L. M. and Johnson, D. A. : Effect of food consistency and starvation on the diurnal cycle of the rat parotid gland. Archs. Oral Biol. 16 : 177-185, 1971.
113) Takeuchi, T., Ogawa, M. and Sugimura, T.: Effects of various hormones and adrenalectomy on the levels of amylase in rat pancreas and parotid gland. Experientia 33: 1531-1532, 1977.

114) Takuma, T., Nakanishi, M., Takagi, Y., Tanemura, T. and Kumegawa, M. : Precocious differentiation of mouse parotid glands and pancreas induced by hormones. Biochim. Biophys. Acta 538 : 376-383, 1978.

115) Kumegawa, M., Takuma, T., Hosoda, S. and Nakanishi, M. : Effects of hormones on differentiation of parotid glands of suckling mice in vitro. Biochim. Biophys. Acta 544: 53-61, 1978.

116) Kumegawa, M., Maeda, N., Yajima, T., Ikeda, E. and Minamide, C.: L-Thyroxine, cortisol and diet affect the level of amylase in the parotid gland of developing rats. J. Endocrinol. 87:65-71, 1980.

117) Kumegawa, M., Yajima, T., Maeda, N., Takuma, T., Minamide, C. and Machino, M. : Synergistic effects of diet, thyroxine and glucocorticoid hormones on amylase activity in parotid glands of growing rats. Archs. Oral Biol. 26 : 631-633, 1981.

118) Cohen, A., Heller, H. and Kulka, R. G. : The effect of hydrocortisone on exportable enzyme accumulation in the differentiating chick pancreas. Develop. Biol. 29 : 293-306, 1972.

119) Cohen, A. and Kulka, R. G. : Induction of chymotrypsinogen by hydrocortisone in embryonic chick pancreas in vitro. J. Biol. Chem. 249 : 4522-4527, 1974.

120) McEvoy, R. C., Hegre, O. D. and Lazarow, A. : Foetal rat pancreas in organ culture. Effect of corticosterone concentrations on the acinar and islet cell components. Differentiation 6 : 17-22, 1975.

121) Clos, J., Crepel, J., Legrand, C., Legrand, J., Rabie, A. and Vigonroux, E. : Thyroid physiology during the postnatal period in the rat: a study of the development of thyroid function and the morphogenetic effects of thyroxine with special reference to cellular maturation. Gen. Comp. Endocrinol.23 : 178192, 1965.

122) Dussault, J. H. and Labrie, F. : Development of the hypothalamic pituitary axis in the neonatal rat. Endocrinology $97: 1321-$ 1324, 1975.

123) Diez, J. A. Sze, P., Y. and Ginsburg, B. E. : Postanatal development of mouse plasma and brain corticosterone levels: new finding contingent upon the use of competi- 
tive protein binding assay. Endocrinology $98: 1432-1442,1976$.

124) Kumegawa, M., Takuma, T., Ikeda, E., Nakanishi, M. and Hosoda, S. : Precocious differentiation of chick embryo pancreas in vitro. Roles of prednisolone, insuline and $\mathrm{L}$ thyroxine. Biochim. Biophys. Acta 585 : 554$562,1979$.

125) Kumegawa, M., Maeda, N., Yajima, T., Ikeda, E. and Hanai, H. : Permissive role of L-thyroxine in induction of pancreatic amylase by cortisol in neonatal rats. J. Endocrinol. 86 : 497-500, 1980.

126) Kumegawa, M., Yajima, T., Maeda, N., Takuma, T. and Hosoda, S. : Permissive role of L-thyroxine in the induction of stomach pepsiongen by cortisol in neonatal rats. J. Endocrinol. $87: 431-435,1980$.

127) Kumegawa, M., Takuma, T., Hosoda, S., Kunii, S. and Kanda, Y. : Precocious induction of pepsinogen in the stomach of suckling mice by hormones. Biochim. Biophys. Acta 543 : 243-250, 1978.

128) Murphy, R. A., Watson, A. Y., Metz, J. and Forssmann, W. G.: The mouse submandibular gland: An exocrine organ for growth factors. J. Histochem. Cytochem. 28:890902, 1980.

129) Gresik, E. W.: Postnatal developmental changes in submandibular glands of rats and mice. J. Histochem. Cytochm. $28: 860-870$, 1980.

130) Tajima, Y., Utsumi, N., Takuma, T. and
Kumegawa, M. : Histochemical study on the localization of glucose-6-phosphate dehydrogenase induced by androgen or thyroxine in the convoluted tubules of mouse submandibular gland. Histochem. 63 : 261-264, 1979.

131) Barka, T., Van Der Noen, H., Gresik, E. W. and Kerenyi T.: Immunoreactive epidermal growth factor in human amniotic fluid. Mt. Sinai J. Med. N. Y. 45 : 679-683, 1978.

132) Carpenter, G.: The regulation of cell proliferation: advances in the biology and mechanism of action of epidermal growth factor. J. Invest. Dermatol. 71 : 283-288, 1978.

133) Carpenter, G.: Epidermal growth factor is major growth-promoting agent in human milk. Science 210 : 198-199, 1980.

134) Maeda, N., Miyoshi, S. and Toh, H. : First observation of a muscle spindle in fish. $\mathrm{Na}$ ture $301: 61-62,1983$.

135) Maeda, N., Miyoshi, S., Ohmori, T. and Toh, H.: Study on the jaw-closing muscle, Adductor mandibulae, on the salmon, $\mathrm{On}$ corhynchus masou. I. Fiber types. Anat. Anz. 157 : 159-166, 1984.

136) Maeda, N., Kumegawa, M., Ukai, M., Kaneko, T., Kurihara, N., Sato, A. and Miyoshi, S.: Anatomical and functional differences in the Adductor mandibulae muscle between Zaco platypus and Carassius gibelio langsdorfi of the Cyprinidae fish family. Anat. Anz. (in press). 